\title{
イネ穂枯れに関する研究
}

\author{
牧野秋雄 - 久永 勝 - 森 喜作*
}

\section{Studies on Ear Blighting of Rice Plant}

\section{Tokio Makino, Masaru Hisanaga and Kisaku Mori}

摘要 : 東海近畿ブロックの 連絡試験として, '69〜 ’70年にイネ穂枯れに関与する病原菌の種類, 葉身の 発病と穗の発病との関係について検討した.

1. 穂枯れに関与する病原菌の主なものはごま葉枯 病菌と認められ，このほかに褐色葉枯病菌も場所によ っては一部関与していると認められた.
2. 1 枚の固場内における薬剤試験の各区の調査例 では, 葉身のごま葉枯病の発病程度と穂首, 枝梗粐など の発病程度と相関関係があると認められた。しかし, 品 種, 移植期などを異にした一般謴場では, 葉身発病と粐 発病とでは相関関係があると認められたが, 穂首発病お よび枝梗発病とは相関関係は認められなかった。

\section{I 緒 言}

穂枯れに関与する病原菌については，1949年の井上 の報告 ${ }^{2}$ 以来, 数多くのものがある ${ }^{10,11,6,12,9,5,4,8)}$. 静 岡県においては, 昭和 30 年に天竜川流域で本病の発生 を認め，すでに「原因ならびに薬剂防除」(6) と題して， その内容を報告し, 平坦地ではごま葉枯病菌が主体を なすが，場所によってはすじ葉枯病菌も関与している ことを明らかにした. その後, 木谷ら4)の全国的な規 模の標本調査や北陸地方, 福島県, 福岡県における小 黒菌核病 $\left.{ }^{1}, 8,13\right)$ や東北地方の褐色葉枯病菌による多発 の事例5)などが報告されている。このように, 地域に よって関与している病菌の種類に若干の差があるもの と考えられたので, 東海近畿ブロック各県の連絡試験 として, 穂枯れの病原菌ならびに葉身発病と穂発病と の関係が検討されることとなった. 前述のように本県 では, 一応の結論を出しているが, その後の品種, 耕 種法, 薬剂の種類の変化などもあるので, 再検討を加 えようとした。

葉身のごま葉枯病の病斑数と穂枯れの発病程度につ いては, 薬剤試験の罴場では相関関係が高いようにか ねてから観察されていたので，これを確認するととも に品種，畕場および移植期をこみにした場合の関係を 検討しようとした. なお, 本調查は東海近畿農試江塚 室長の指導によってなされたものである。記して感謝 の意を表したい.

\section{III穂枯れに関与する病原菌の種類調査}

連絡試験の調査は '69〜'70 年の 2 カ年おこなわれ たが，'67〜'68 年の結果をも合わせて検討することに した.

\section{1. 調查方法}

'67〜'68 年には, 発病枝梗または粐を常法の昇承・ アルコール法によって表面殺菌をおこなったのち調べ た. '69〜'70 年には北陸農試法に従って，1cm 位の 長さに切断した発病枝梗または粐をビンに入れ, 水道 水を入れて手で 30 回強く振盪することによって洗浄し， さらに水を加えて, 同柡の洗浄を計 5 回くりかえし, 水道水で湿らせたろ紙をしいたシャーレ湿室内に洗浄 ずみの材料を入れ，25〜 $28^{\circ} \mathrm{C}$ の定温器に 2 昼夜保ち, 材料に生じた菌を直接鏡検した。

\section{2. 調查結果}

第 1 表に結果を示した。これによると, 各地から採 集した発病枝梗, 粐から高率にごま葉枯病菌 (Helminthosporium 菌) が検出され, そのほかに, 褐色葉枯病 (Fusarium nivale 菌,) Curvularia 菌, Alternaria 菌, Nigrospora 菌, Cladosporium 菌, Fusarium 菌, Phoma 菌, Epicoccum 菌などが検出された。なお, 肉眼的病 徵からいもち病と判別できる標本は除外して調べたた めに, いもち病菌 (Pyricularia 菌) は静岡市富厚里の 材料でわずかに認められたのみであった。このうち， ごま葉枯病菌, 褐色葉枯病菌は穂に対する強い病原性 
牧野秋雄・久永 勝・森 喜作 : イネ穗枯れに関する研究

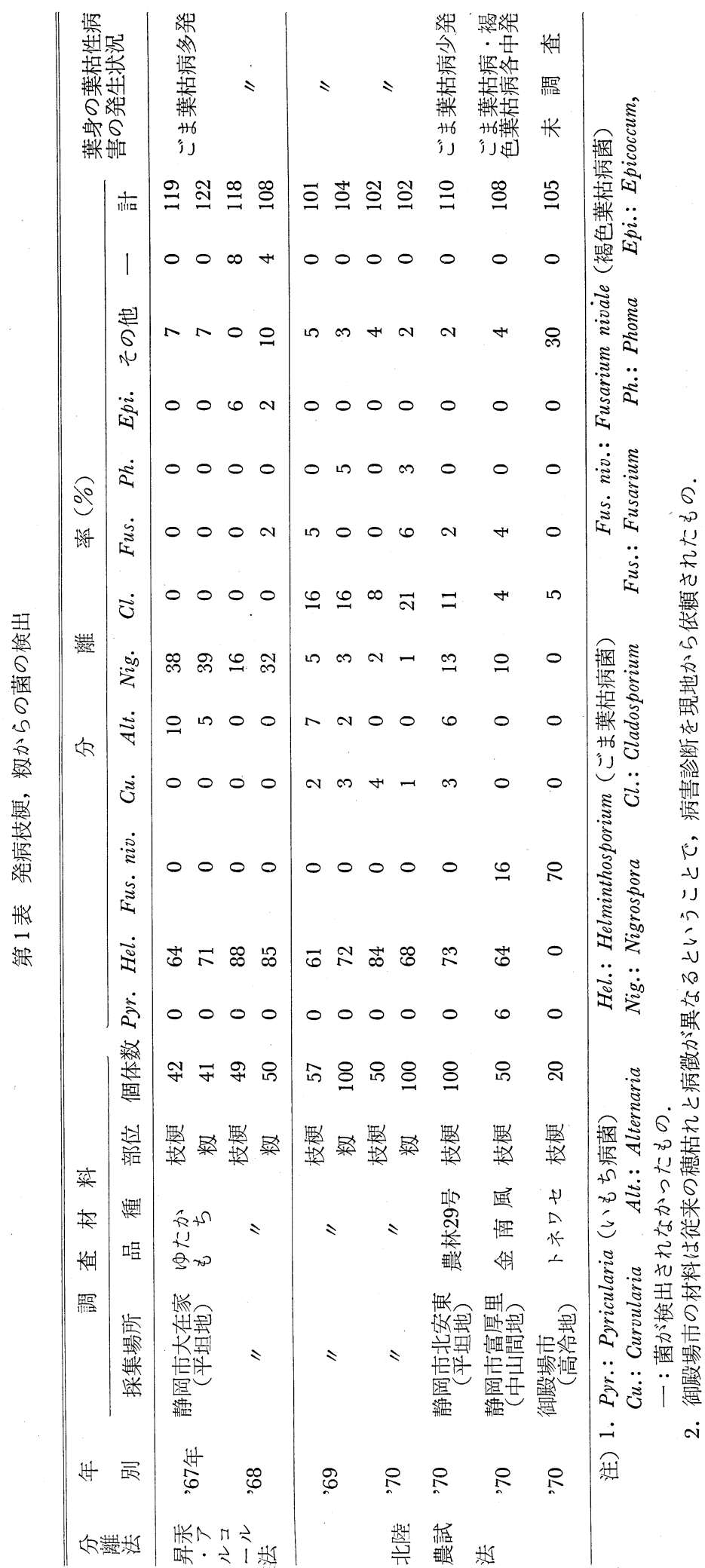


が,また, Alternaria菌, Curvularia菌は弱い病原性が, それぞれ朴谷ら によよて郝告されている。これらの 材料を採集した㽬場のうち，静岡市大在家はごま葉枯 病多発田, 静阔市北安東はごま葉枯病少発田, 静岡市 富厚里はごま葉枯病と褐色葉枯病の混発田であった。 '67〜'70 年に静岡市大在家の同一直場で関与する菌の 年次変動を調べたところ，ごま葉枯病菌が主体と認め られた。なお，その他の菌については '67〜'68 年に は Nigrospora 菌が, '69〜'70年には Cladosporium 菌 が多かったが，これは，三浦ら5)の指摘するように分 離法の違いによるものと思われる。

\section{III 葉身のごま葉枯病の発病と穂の発 病程度との関係}

\section{1. 調查方法}

(1) 薬剂防除試験国場における調査

’69年に静岡市大在家において，品種ゆたかもちを栽 培し薬剂効果比較試験を実施したが，その蕾場におい て葉身のごま葉枯病を乳熟期と成熟期に。穂の発病を 成熟期に調査して，両者の関係を検討した。調查法の 詳細はつぎのとおりである，葉身のごま葉枯病 : 乳熟 期 (出穂約 13 日後) と成熟期（出穂約50日後）に任意 に10株選び, 各株 3 茎について上位 3 葉の葉身中央部 $5 \mathrm{~cm}$ 間の病斑数を数えた。穂発病 : 成熟期に 10 株につ いて発病穂首率，10茥について発病枝梗率と発病粐率 （粐面積の $5 \%$ 以上の変色を発病籾とした）を調べた.

（2）一般圂場における調査

’70年に, 品種, 場所, 移植期などを異にした囯場に おいて, ’69年の調査法に準じて，成熟期に葉身のごま 葉枯病と穂枯れの発病を調べ, 検討した。

\section{2. 調查結果}

（1）薬绪防除試験國場における調査結果

結果は第 2 表に示した。これによると同一直場内の

第 2 表 葉身のごま葉枯病の発病と穂の発病程度 との相関関係 '69年 (同一亩場内, 同一品種, 薬剂試験 の各区の調査, $\mathrm{n}=45$ )

\begin{tabular}{llc}
\hline & \multicolumn{3}{c}{ 葉身 $5 \mathrm{~cm}$ 間のごま葉枯病病斑数 } \\
\cline { 2 - 3 } & 乳 熟 期 & 成 熟 期 \\
\hline 発病穂首率 & $\mathrm{r}=0.695 * * *$ & $\mathrm{r}=0.713 * * *$ \\
発病枝梗率 & $\mathrm{r}=0.751$ *** & $\mathrm{r}=0.769 * * *$ \\
発病粐率 & $\mathrm{r}=0.717 * * *$ & $\mathrm{r}=0.796 * * *$ \\
\hline
\end{tabular}

注）***印は $99.9 \%$ 水準の有意性を示す.

薬剂試験区の延べ45区について，乳熟期または成熟期 の葉身のごま葉枯病の発病程度と成熟期の発病穂首率, 発病枝梗率, 発病粐率などとの相関係数を求めたとこ ろ, いずれも相関関係があると認められた，また，葉 身のごま葉枯病の発病については, 乳熟期と成熟期と の両者間に相関係数 $\mathrm{r}=0.659 * * *$ が得られた, なお, この圂場における穂枯れに関与する主な菌はごま葉枯 病菌と認められた。

（2）一般国場における調査結果

品種, 圂場, 移植期などを異にした21甬場について， 成熟期の葉身のごま葉枯病の発生程度と発病穂首率, 発病枝梗率, 発病粐率との関係および, これらの調査 結果をグループ分けして相関係数を求めたものを第 3 表に示した。

これによると，全体をこみにしたものでは，発病穂 首率, 発病枝梗率では相関関係は認められなかった。

第 3 表 葉身のごま葉枯病の発病と穂の発病程度との相関関係 '70年（異围場, 異品種)

\begin{tabular}{|c|c|c|c|c|c|}
\hline & 料 & 調查圂場数 & 発病穂首率 & 発病枝梗率 & 発病粐率 \\
\hline & 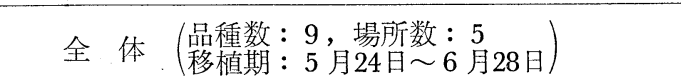 & 21 & $r=0.028$ & $\mathrm{r}=0.425$ & $\mathrm{r}=0.792$ \\
\hline $\begin{array}{l}\text { グ } \\
\text { ル } \\
1 \\
\text { プ }\end{array}$ & $\begin{array}{l}\text { (1)同一品種 : 農林29号, 同一場所 : 場内, 異移植期 : } \\
5 \text { 月24日〜 } 618 \text { 日 }\end{array}$ & 5 & $\mathrm{r}=0.303$ & $\mathrm{r}=0.445$ & $\mathrm{r}=0.722$ \\
\hline $\begin{array}{l}\text { 分 } \\
\text { け } \\
\text { 之 }\end{array}$ & $\begin{array}{l}\text { (2)異品種 : ハルカゼ, 日本晴, 金南風, 農林 } 29 \text { 号, ミ } \\
\text { ホニシ 中系 } 314 \text {, 同一場所 : 場内, 同一移植期 } \\
\text { : } 6 \text { 月 } 8 \text { 日 }\end{array}$ & 6 & $r=0.090$ & $\mathrm{r}=0.322$ & $\mathrm{r}=0.975^{* * *}$ \\
\hline $\begin{array}{l}\text { た } \\
も \\
\text { の }\end{array}$ & $\begin{array}{l}\text { (3)同一品種: 金南風, 異場所 : 場内, 富厚里, 北安東 } \\
\text { ほぼ同一移植期 : } 6 \text { 月14日 15日 }\end{array}$ & 4 & $r=0.920$ & $\mathrm{r}=0.996$ & $\mathrm{r}=0.931$ \\
\hline
\end{tabular}

注）**，***印は，それぞれ99\%，99.9\%水準の有意性を示す， 
しかし, 発病粐率では高い相関関倸があると認められ た．またこれらをグループ分けして検討した結果で は, いずれの場合も発病粐率では高い相関係数が得ら れたのに対して, 発病穂首率と発病枝梗率では, 同一 品種をほほ同一時期に移植したものに限って, 高い相 関係数が得られたにすぎなかった，ちなみにこれいら の围場に打ける穂枯れに関与する菌の主体はごま葉枯 病菌と認められた。

\section{IV 考察}

現在までの数多くの研究によって, 穂枯れをおこす 病原菌の主役はごま葉枯病菌であり, 地域または国場 によってはすじ葉枯病菌, 褐色葉枯病菌, 小粒菌核病 菌（主として小黒菌核病菌）なども関与しているとさ れている。本県における過去の調查6)でも, ごま葉枯 病菌が主役を演じ, 場所によってはすじ葉枯病菌が関 与しているとの結果を得た，今回の小規模な調査でも， ごま葉枯病菌が主体と認められたが，そのほかに，場 所によっては褐色葉枯病菌も関与していると認められ た. な京, 膡場の葉枯性病害の発生状況から, ごま葉 枯病菌, すじ葉枯病菌, 褐色葉枯病菌のいずれかまた は複数の主役菌を推定することができそうであると認 められた。また，ごま葉枯病多発田の 4 力年の調査例 では, 関与する菌の主役はごま葉枯病菌であり, 主役 菌の年次変動は少ないようにみられた。ここには成績 は示さなかったが, えそモザイク病に罹病して出すく みになった穂のみごに小黒菌核病の多発例を認めた。 北陸地方などでは一般的に小黒菌核病による穂枯れが みられるようであるが, 本県では倒伏したイネ以外で の穂部の発病は例外的なことのようである。

以上のとおり, 本県では主役菌はごま葉枯病菌であ り, 闻場または地域によってはすじ葉枯病菌, 襡色葉 枯病菌なども関与しているように認められた。

葉枯性病害の発生と穂枯れに関与する菌の種類と関 係がみれらることが多いとするものと年,7,10,11)，その ような見方は危険であるとする見解 3 , 8 とがある。後 者の場合には，葉および穂に発生するいもち病を含め ている場合が多いようである. 著者らの今回の調査で は，いもち病によるものは除外して検討した，すなわ ち, 明らかに穗いもちと判別されるものを除いたいわ ゆる「穂枯れ」の発病と葉身のごま葉枯病との関係を 検討した，その結果，一枚の国場内における薬剤試験 の各区における例では, 乳熟期または成熟期の葉身の ごま葉枯病の発病程度と発病穂首率, 発病枝梗率, 発 病粐率などとの間に相関関係がみられた。しかし, 品
種，長期にわたる移植期などをこみにした場合には， 葉身発病と発病粐率との間には相関関係がみられたが, 葉身発病と発病穂首率, 発病枝梗率との間には相関関 係はみられなかった。これは, 穂首発病や枝梗発病は 黄熟期ごろからみとめられ, 成熟期にかけて急激に增 加するが,この間わずかな生育ステージの差や, 出穂 後の経過日数などが穂枯れの増加に著しく影響するた めと思われる。しかし, 葉身のごま葉枯病の病斑数の 増加は, 穂首や枝梗発病とは異なり, 登熟後期におい て急激にみられることは少ないようである.すなわち， 登熟後期の葉身の病斑数の変化は少ないが, 穂首, 枝 梗の発病増加はわずかの条件によって急激に変動する ものと認められる。これが葉身の病斑数と穂首, 枝梗 発病との相関関係を低くしている原因と思われる。し かし, 粐への感染, 発病はすでに明らかにしたよう $k^{6)}$, 穂ばらみ末期から出穗 1 週間以内にとどまるも のが多く，登熟後期の感染はあまり多くない，このた め, 葉身のごま葉枯病病班数と粐発病との間に高い相 関関係が成立するものと理解される。

\section{引用文 献}

1）焁木忠雄 (1969): 北日本病虫研報, 20：25.

2）井上義孝 (1949)：九州農事研究発表会講要, 4 : $10-12$.

3）木谷清美（1966）：四国植物防疫研究，1：54一 56.

4）木谷清美 ·大畑貫一 一久保干冬（1970）：四国農 試報, 22：27-118.

5）三浦喜夫 · 斉 伴男 (1968)：北日本病虫研報, 19: 11 .

6) 森 喜作・松田 明 (1963)：静岡農試研報, 8 : 43-62.

7）島田尚光 ·茂木静夫 ·平山成一（1960）：日植病 報, 25: 7-8. (講要)

8) 鈴木穂積・山口富夫 (1972): 北陸農試報, 14 : 63-90.

9）上原 等・都崎芳久 - 山本辰夫 (1967): 四国植 物防疫研究, $2: 1-8$.

10）内海 繁 (1951)：新鼬農試速報, $10 ： 5-8$.

11) — (1952): 新潟農試速報, 13: 11-14.

12) 安 正純·柿崎 正 · 深津量栄 ·島田尚光 (1962) ：指定試験 (病虫), $1 ： 1-229$.

13）横山佐太正 ·吉田桂輔 · 吉村大三郎 (1971)：日 植病報, 37: 164 (講要): 


\section{Summary}

1. The kind and frequency of causal fungi responsible for ear blighting of rice plant were examined at some localities in Shizuoka Prefecture from 1967 to 1970 . The results showed that the most important pathogen of ear blighting was Helminthosporium oryzae (=Cochliobolus miyabeanus). In some instances, Fusarium nivale was also found to be responsible for ear blighting.

2. The relationship between severity of ear blighting and that of Helminthosporium leaf spot on leaf blade was investigated under various field conditions. In the plots of a field test for fungicidal effect, correlation coefficient was as high as $0.695 * * *$ to $0.796 * * *$ between the number of leaf spots and the percentage of diseased necks, panicle branches or kernels. In the fields different in variety, locality or transplanting time, high correlation coefficient of $0.792 * * *$ was obtained only between the number of leaf spots and the percentage of diseased kernels, while no significant correlation was found between the number of leaf spots and the percentage of diseased necks or panicle branches.

(昭47.12.1. 受付) 